
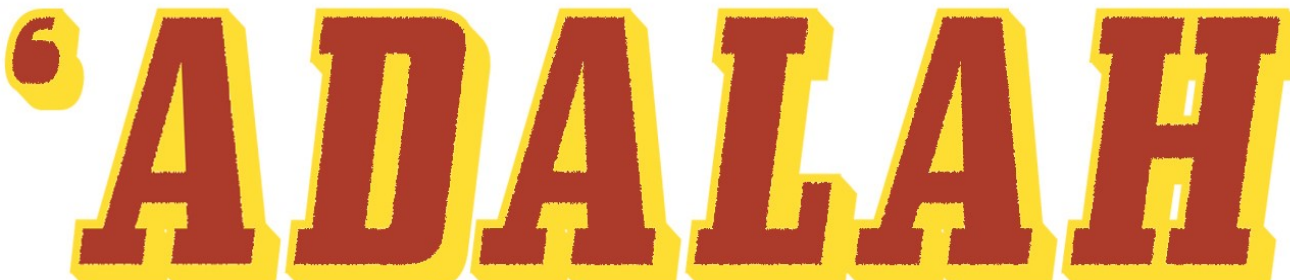

ADALAH : Buletin Hukum \&

Keadilan

@adalahuinjkt

Buletin Hukum \& Keadilan

\title{
Calon Tunggal Sebagai Wujud Disfungsi Partai Politik
}

Nur Rohim Yunus*

Fenomena calon tunggal pada pemilihan umum kepala daerah serentak mewarnai suhu politik di Indonesia. Hal ini bermula pada tahun 2015 dengan terdapatnya tiga daerah dan tahun 2017 terdapat sembilan daerah, dan kemungkinan masih tetap ada dalam pemilukada berikutnya.

Munculnya fenomena ini disebabkan karena kurangnya partisipasi partai politik untuk mengajukan kader-kader terbaik dari masing-masing partai, sehingga berdampak pada terjadinya liberalisasi politik untuk memenangkan satu pasangan calon saja.

Keberadaan calon tunggal mengakibatkan peniadaan kontestasi. Pemilu tanpa Kontestasi hakikatnya bukan pemilu yang senafas dengan asas luber dan jurdil. Hak-hak untuk memilih dan hak dipilih akan terkurangi dengan adanya calon tunggal, karena pemilih dihadapkan pada pilihan artifisial (semu).

Aspek negatif dari adanya calon tunggal ini mengakibatkan masyarakat tidak bisa membandingkan pasangan calon, dikarenakan hanya ada satu pasangan calon saja. Padahal boleh jadi masih ada calon lain yang lebih baik yang dapat dipilih oleh masyarakat. Selain dari adanya satu pasangan kepala daerah menimbulkan kurangnya respon masyarakat untuk datang ke tempat pemilihan umum untuk memilih

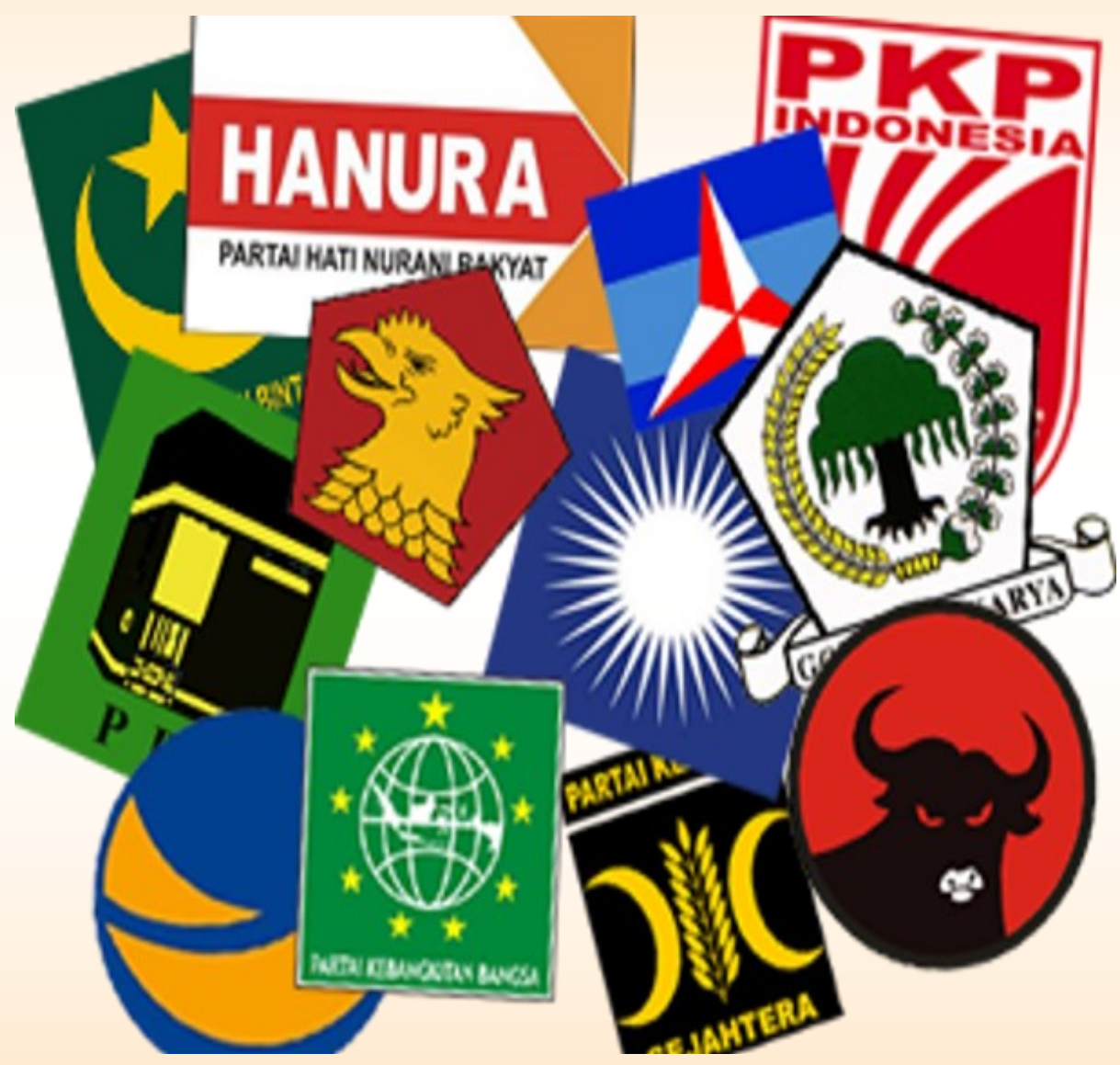

calon kepala daerah yang hanya satu pasangan.

Landasan hukum dibolehkannya calon tunggal adalah adanya putusan MK Nomor 100/PUUXIII/2015 yang menentukan mekanisme baru dalam pelaksanaan pilkada serentak, yaitu dengan memberikan peluang bagi satu pasangan calon kepala daerah, baik gubernur/wakil gubernur, bupati/wakil bupati, maupun walikota/wakil walikota untuk mengi- kuti kontestasi pilkada serentak melalui mekanisme memilih "setuju' atau "tidak setuju'.

Dasar penetapan MK untuk melegalkan calon tunggal, lebih kepada penerapan pasal 18 ayat (4) UUD NRI 1945 yang menghendaki pemilihan secara demokratis. Pilihan makna demokrasi yang ditetapkan oleh masyarakat melalui wakilwakil di parlemen menjatuhkan pilihan makna demokratis pada proses pemilihan secara langsung dengan 
pemilihan umum oleh KPU (Dhesinta, 2016: 89).

Dasar pertimbangan secara yuridis pemilukada dengan calon tunggal yakni adanya wujud penjawantahan pelaksanaan pasal 1 ayat (2) UUD NRI 1945 yang hakikatnya pemenuhan hak rakyat untuk memilih dan dipilih sebagai wujud kedaulatan rakyat. Hal ini pun tertuang dalam pasal 1 angka 1 Undang-Undang Nomor 8 tahun 2015. Sedang secara filosofis pemilukada dengan calon tunggal tetap diadakan sebagai upaya penjaminan terpenuhinya hak konstitusional warga negara untuk dipilih, sehingga pilkada tetap diadakan, meskipun hanya memiliki satu pasangan calon saja. Hal ini pun menjadi mandat akan pelaksanaan kedaulatan rakyat sebagai perwujudan kedaulatan tertinggi.

Secara sosiologis, pelaksanaan pilkada dengan calon tunggal dapat dianggap labil demokratis, karena rakyat menentukan pilihannya terpaksa harus setuju atau tidak setuju. Hal ini berbeda bila dilakukan dengan cara aklamasi, sehingga rakyat dapat turut serta secara personal menentukan suaranya.

Pernyataan setuju atau tidak setuju ini cenderung mengikuti pola referendum, sebagaimana yang digunakan oleh negara dalam melakukan jejak pendapat.

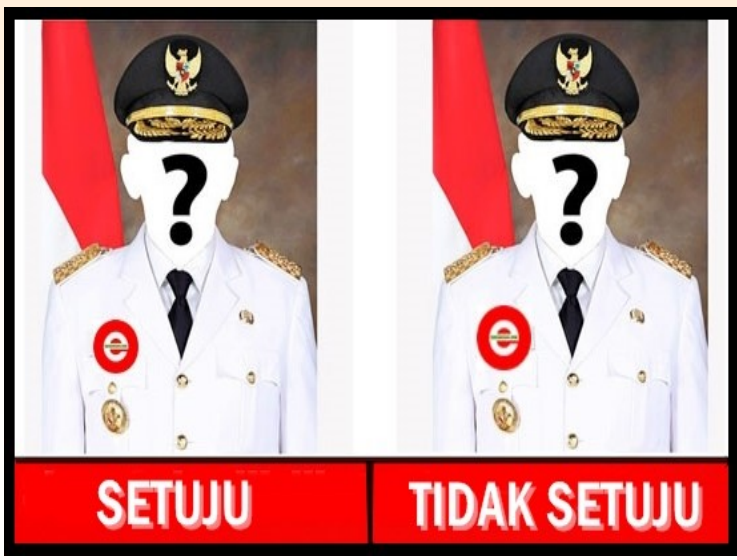

(Budiardjo, 2000: 163-164). Berdasarkan UndangUndang No. 2 Tahun 2008 tentang Partai Politik, disebutkan fungsi-fungsi partai politik dalam Pasal 11 ayat (1) diantaranya adalah sebagai rekrutmen politik dalam proses pengisian jabatan politik melalui mekanisme demokrasi dengan memperhatikan kesetaraan dan keadilan gender.

Hal ini dikuatkan kembali oleh Maryam Nur Hidayati dalam jurnalnya yang menyatakan bahwa (Hidayati, 2016: 55):

"Partai politik sebagai representasi dari aspirasi masyarakat diberikan hak khusus yaitu dalam pengajuan calon kepala daerah. Partai Politik mempunyai kewajiban mengajukan pasangan calon karena mereka mempunyai suara dan kursi. Selain itu, partai politik adalah institusi yang sah dan legitimate untuk mengajukan pasangan
calon dalam pemilihan kepala daeDalam pola referendum ini, apabila jumlah suara lebih banyak menyatakan setuju kepada calon kepala daerah maka calon kepala daerah tersebut terpilih oleh masyarakat untuk memimpin daerah tersebut. Akan tetapi, apabila jumlah suara yang menyatakan tidak setuju terhadap kepala daerah lebih banyak dari yang setuju, maka dilakukan penundaan pemilihan kepala daerah karena rakyat telah menentukan pilihannya, maka penundaan tersebut tidak dianggap bertentangan dengan konstitusi.

Apabila mau dicari akar masalah, maka partailah yang menjadi pemicu terjadinya calon tunggal, karena partai politik yang ada tidak mau menjalankan fungsinya dalam melakukan rekrutmen politik. Menurut Miriam Budiardjo, fungsi partai politik selain sebagai pilar demokrasi juga menjadi sarana komunikasi politik, sosialisasi politik (political socialization), sarana rekrutmen politik, dan pengatur politik hanya ada satu calon saja dalam ajang pesta demokrasi. Sehingga akhirnya patut diamini, bahwa partailah yang belum mampu menjalankan fungsinya dengan maksimal, belum mampu menghadirkan hadiah terbaik untuk kemajuan demokrasi di negeri Indonesia tercinta.

\section{Pustaka Acuan:}

*Penulis adalah Sekjen Pusat Studi Konstitusi dan Legislasi Nasional (Poskolegnas) UIN Syarif Hidayatullah Jakarta.

Budiardjo, Miriam, Pengantar Ilmu Politik, Jakarta, Gramedia, 2000.

Dhesinta, Wafia Silvi. 2016. "Calon Tunggal Dalam Pemilihan Umum Kepala Daerah Dalam Konsep Demokrasi." JURNAL CITA HUKUM. Vol. 4, No. 1 Juni.

Hidayati, Maryam Nur. 2016. "Problematika Hukum Calon Tunggal dalam Pemilihan Kepala Daerah Serentak Tahun 2015." Jurnal Lex Renaissance. Vol. 1 No. 1 Januari.

'Adalah; Buletin Hukum dan Keadilan merupakan berkala ilmiah yang diterbitkan oleh Pusat Studi Konstitusi dan Legislasi Nasional (POSKO-LEGNAS), Fakultas Syariah dan Hukum UIN Syarif Hidayatullah Jakarta.

Penasehat: Prof. Dr. H. Abdul Ghani Abdullah, SH., Prof. Dr. H. A Salman Maggalatung, SH., MH. Pemimpin Redaktur: Indra Rahmatullah, Tim Redaktur: Nur Rohim Yunus, Fathuddin, Mara Sutan Rambe, Muhammad Ishar Helmi, Erwin Hikmatiar. Penyunting: Indah Furba, Hasin Abdullah. Setting \& Layout: Siti Anisaul Kamilah. 